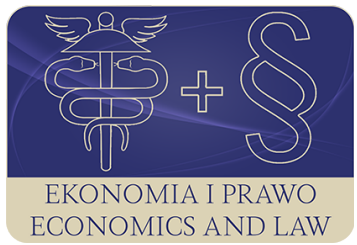

EKONOMIA I PRAWO. ECONOMICS AND LAW

Volume 17, Issue 3, September 2018

p-ISSN 1898-2255, e-ISSN 2392-1625

www.economicsandlaw.pl

ORIGINAL ARTICLE

received 02.01.2018; revised 08.05.2018; accepted 30.09.2018

Citation: Zieliński, M. (2018). Effect of the economic situation on employment and its structure in the Central and Eastern European countries. Ekonomia i Prawo. Ecomomics and Law, 17(3):

329-337. doi:10.12775/EiP.2018.024.

\title{
Effect of the economic situation on employment and its structure in the Central and Eastern European countries
}

\author{
MARIUSZ ZIELIŃSKI \\ Opole University of Technology, Faculty of Economics and Management, Department \\ of Organization and Enterprise Management, ul. Luboszycka 7, 45-036 Opole, Poland \\ $\square$ m.zielinski@po.opole.pl
}

\begin{abstract}
Motivation: The Central and Eastern European countries suffered from a decrease in professional activity and increases in unemployment, income inequality, and underemployment. In most of the countries in the region, it was decided to increase labour market flexibility, adopting a Western European model of labour market functioning. The effects of deregulation (flexibility increase) for the labour market depend to a great extent on the economic situation.

Aim: The paper attempts to answer the question of the degree to which changes in the employment level and structure can be explained by changes in the economic situation. The article verified two hypotheses: 'the employment level reacts to changes in the economic situation; however, this reaction in the Central and Eastern Europe-

an countries is more severe than the average reaction in the European Union' $(\mathrm{Hl})$ and 'changes in the economic situation determines to a very large extent the employment level in the groups experiencing discrimination (women, youngest and oldest people) more than for employees in general' (H2).

Results: In the majority of the examined countries, a statistically significant correlation occurs between changes in GDP and total employment level; but for all analysed countries as a whole, the influence of changes in GDP on the employment level is not greater than the European Union's average. The data do not indicate discrimination against certain groups (women, young people, people in pre-retirement age), changes in the employment
\end{abstract}




\section{levels of the aforementioned groups are less dependent on the economic situation than} the changes in total employment.

Keywords: economic growth; employment; discrimination on the labour market; Central and Eastern European countries; European Union

JEL: E24; E32; J16; J21; J70

\section{Introduction}

After changing the economic system, the Central and Eastern European countries suffered from a decrease in professional activity and increases in unemployment, as well as deterioration of the situation of groups discriminated against on the labour market. To reduce the disequilibrium in the labour market, in most of the countries in the region, it was decided to increase labour market flexibility, adopting a Western European model of labour market functioning (Babos, 2014, pp. 45-48).

The effects of deregulation for the labour market depend to a great extent on the economic situation (Eamets \& Jaakson, 2014, pp. 747-749; Zieliński, 2015, pp. 188-189). The scale of the reaction of the economy to changes in economic conditions in the form of changes in the employment level and structure depends on, among other factors, legal regulations concerning the regulation of labour market functioning (Babos, 2014, pp. 40-42). The greater the legal protection is for employment relationships, and the higher the share of standard employment is in the particular economy, the more difficult it is to adjust the employment level to the current company's needs in a short period of time.

The paper attempts to answer the question of the degree to which changes in the employment level and structure can be explained by changes in the economic situation. The analysis of the 11 selected countries of Central and Eastern Europe has also to answer the question, is there the discrimination against women, youth and the oldest people on their labour markets (from a macroeconomic point of view).

\section{Literature review}

The rate of change in economic growth translates into change in the situation of the labour market in a short time, depending on the level of the market's flexibility. On the macroeconomic scale, it is assumed that an increase in labour market flexibility contributes to an increase in economy competitiveness. Deregulation induces deepening of labour market segmentation, which is heterogenic both on the demand and supply sides; additionally, it functions under the condition of incomplete information regarding offers on both sides of the market. The differentiation of employers' and employees' offers is encompassed by the model of a dual labour market (Reich et al., 1973, pp. 360363). The conception of a dual labour market is primarily related to demand 
side segmentation. According to this concept, the economy might be divided into a primary sector (strong economic organisations achieving high profitability and offering stable workplaces with beneficial working and pay conditions) and a secondary sector (small and medium enterprises that strongly vulnerable to economic fluctuations, offering low-paid and unstable workplaces) (Dustmann et al., 2010, p. 13).

The human capital theory relates to supply side segmentation. According to this theory, the possibility of obtaining employment by the employee, as well as expected income, depend on his/her human capital, which is defined as a resource of knowledge, skills, abilities, qualifications, attitudes, motivation and health, translating into his/her productivity (Madsen \& Bingham, 2014, p. 5 ). The human capital differentiation of individual employees is intensified by employers in the secondary sector, who invest less in employees (for example, in training) (Fouarge et al., 2012, pp. 180-181).

There are fewer companies belonging to the primary sector in the Central and Eastern European countries than in UE, so the first research hypothesis $(\mathrm{Hl})$ of article is stated: the employment level reacts to changes in the economic situation; however, this reaction in the Central and Eastern European countries is more severe than the average reaction in the European Union.

The company can conduct segmentation of the internal labour market and divide the present employees into at least two groups: 'core' and 'periphery' resources (Walsh \& Deery, 1999, p. 50). Core resources consist of employees who are necessary for realisation of the basic company functions that require adequate experience and competencies, the peripheral part of the staff is employed depending on the economic situation with low working and pay conditions, often in flexible employment forms (Burgess \& Connel, 2006, pp. 130-133).

Under the conditions of an employer's market, which occurs in times of economic crisis (when the demand side of the labour market is the minority), company decisions regarding employment size and structure determine the situation on the labour market. In periods of recession, the least efficient employees lose their jobs. Redundancy especially concerns the groups with unfavourable social-economic characteristics (perceived by employers as potentially less productive). According to the literature review and empirical research, the groups that might be affected by discrimination, manifesting as higher unemployment levels, lower pay levels and hindered access to the primary market, are women (Shortland, 2009, pp. 367-376), people with low qualifications (low-skilled workers) and low education levels (Belan et al., 2010, pp. 776-778, Charlot \& Malherbet, 2013, pp. 3-6), young people, and older people losing their jobs (Rutkowski, 2006, pp. 25-28), as well as immigrants and ethnic minorities (Sa, 2011, pp. 624-631).

Among the groups discriminated against on the labour market, informal or unregistered employment is more frequent, connected with considerably worse pay conditions than on the formal labour market (Charlot et al., 2013, pp. 192194; Williams, 2009, pp. 344-346). The considerations above are connected 
with the second hypothesis (H2): changes in the economic situation determines to a very large extent the employment level in the groups experiencing discrimination (women, youngest and oldest people) more than for employees in general.

\section{Methods}

The assessment of the influence of the pace of economic growth on employment and its structure on the labour markets of Central and Eastern European countries (Bulgaria, Czech Republic, Croatia, Estonia, Hungary, Latvia, Lithuania, Poland, Romania, Slovakia, Slovenia) was performed on the basis of data published by Eurostat (2017). The introduction to the considerations is the presentation of changes in the level of economic growth in EU-28 and in the examined countries during the research period. The basis for calculation are changes in economic growth in percentage form, as well as accompanying changes in the employment level in percentage form. Based on them are calculations of correlation coefficient and coefficient of determination, which are used to verify the hypotheses stated. The pace of GDP change is used as an explanatory variable in all of the sections. Response variables are selected as the total employment level, the employment level of the groups potentially discriminated against on the labour market (women, people from the youngest and oldest age groups). The calculations are performed based on chain indices (which change year to year) of the employment levels in the analysed sections. Chain indices are directly calculated on the basis of Eurostat (2017) data (in the case of women) and on the basis of employment rate and population (in the case of selected age groups). The choice of potentially disadvantaged groups on the labour market (women and the youngest and oldest people) is determined by the availability of data published by Eurostat (2017). The research period encompassed the years 2004-2015. The data related to the analysed countries were compared with the data characterising the entire European Union (EU-28).

\section{Results}

In the first four years analysed (2004-2007) performed economic growth in all 11 studied economies. This increase was faster than the average for the European Union, the exception was Hungary, which in 2007 received only $0.4 \%$ GDP growth (table 1). The occurrence of periodic recessions differed analyzed economies (Lenart et al., 2016, p. 782). From the geographical perspective, the analysed countries can be divided into three groups, i.e. Baltic countries (Estonia, Latvia, Lithuania), countries of the Visegrad group (Czech Republic, Hungary, Poland, Slovakia) and Balkan countries (Bulgaria, Croatia, Romania, Slovenia). The deepest recession affected the Baltic countries, the recession in the Visegrad countries was close to the EU-25, while in the Balkan countries it was slightly deeper than in the EU-25. The worst situation among the analyzed economies occurred in Croatia, where the recession lasted for the period of 2009 to 2014. 
In the Czech Republic and Slovenia, economies recorded the recession in 2009 and 2012-13 years. In Hungary recession occurred in 2009 and 2012, in Slovakia recession occurred in 2009 and 2014 year. In Estonia and Latvia, deep recession has already occurred in 2008 and lasted until 2009 (Estonia) and 2010 (Latvia). In Lithuania recession appears only in 2009, but it was the deepest of the observed economies (reaching almost 15\%). In Bulgaria recession occurred only in 2009, in Romania in the period 2009-2010 (but in 2010 the recession was very shallow). In Poland it occurred only a slowdown in economic growth, without recession. Economies included in the analysis achieved a much lower rate of economic growth after 2008 than in the period 2004-2007.

Total employment changes according to the business cycle. In the first half of analysed period the highest employment level was achieved by most of the economies in 2008, preceding the first recession period (in Hungary, employment was the highest in 2006, in Lithuania, Estonia and Latvia, it was highest in 2007 and in Poland, it was highest in 2009). Countries that managed to rebuild employment levels are Hungary and Poland (where employment in 2015 is the highest in the analyzed period) and the Czech Republic (where employment in 2015 reached the level of 2008). In the remaining eight economies, the employment rate in 2015 was lower than that recorded before the economic crisis (Eurostat, 2017).

Linear regression pictures well the tendencies to increase the level of employment as the economy grows. The linear relationship between employment and GDP growth occurs for the period 2004-2015 in all analysed economies and the EU-25. Table 2 presents an estimate of the influence of GDP on total employment changes, correlation with the statistical significance level of $\mathrm{p}<0.05$ appears in the scale of the EU-28 and in seven of the analysed economies. In the three of economies, the changes in GDP and employment level occur in the same direction, but their relationship is not statistically significant.

The highest correlation between GDP growth and employment level was observed in the Baltic countries. For each of them, the correlation coefficient is statistically significant and the coefficient of determination was higher than $50 \%$, which indicates a serious relationship between the economic growth and the level of total employment. In the case of the Visegrad group, the correlation coefficient was statistically significant for two of them, similarly in the Balkan countries. The coefficient of determination was higher than $50 \%$ only in two of Balkan countries (Bulgaria and Slovenia), and in none of Visegrad group countries. Considering the correlation coefficient and the coefficient of linear determination presented in table 2, the second part of hypothesis $\mathrm{Hl}$ is not positively verified because the employment level in the Central and Eastern European countries reacts to changes in the economic situation more weakly than the EU-28 average. The same results were provided by the analysis presented by Gędek et al. (2017, p. 56) - in the countries with stable market economy the level of employment reacts to the GDP changes more strongly than in the economies after transformation. 
The correlation coefficient between GDP changes and changes in the level of employment of women, at the significance level of $\mathrm{p}<0.05$, occurred in the scale of the EU-28 and in three of the analysed economies. In all analysed economies, the changes in GDP and level of employment of women occur in the same direction, but their relationship is not statistically significant. The coefficients of determination for employment of women divided by the pace of economic growth are greater in three economies (Bulgaria, Estonia and Latvia), than the EU-28 average. Only in these three economies the coefficient of determination was higher than $50 \%$. For all analysed economies, coefficients of determination for employment of women are less than the coefficients of determination of total employment and the pace of economic growth.

The correlation coefficient between GDP change and change in the level of employment of young people (employees aged 15-24 years old), with the significance level of $\mathrm{p}<0.05$, occurs only in three of the examined economies. In other economies, the correlation coefficient was statistically insignificant, in Poland there was a negative correlation coefficient. Negative (and statistically insignificant) correlation between GDP growth and employment in the 15-24 age group in Poland may result from demographic processes (decrease in the number of people in these age groups). The coefficients of determination for the employment level of young people divided by the pace of economic growth are less than the coefficients of determination for the total employment level divided by the pace of economic growth.

In all the analysed economies (and EU-28), the coefficients of determination for the employment level of people in pre-retirement age divided by the pace of economic growth are less than $50 \%$. The economic situation has a low impact on the employment level of people in pre-retirement age (employees aged 55-64 years old). In only two countries (Croatia and Slovakia), the correlation coefficient was statistically significant between the GDP change and the change in the employment level of people in pre-retirement age at the significance level of $\mathrm{p}<0.05$. It should be emphasized that occurred in these cases negative correlation, that is the level of employment age group 55-64 years reacts inversely to the economic situation. In other economies, the correlation coefficient was statistically insignificant, in Hungary there was a positive correlation coefficient. In all the analysed economies, the coefficients of determination for the employment level of people in pre-retirement age divided by the pace of economic growth are less than $50 \%$. This low influence of economic situation on the employment level of people in pre-retirement age might be a result of, among other factors, the desire to extend the professional activity of the population, partially forced by legal changes aimed at the reduction of the possibility of early retirement.

Considering the eleven analysed economies as a whole, it should be stated that the influence of GDP on total employment was more often statistically significant than employment of the potentially discriminated against groups on the labour market. In connection with the above considerations, hypothesis 
$\mathrm{H} 2$, stating that changes in the economic situation determine to a very large extent the employment level of the disadvantaged groups (women and the youngest and oldest people) more than for the general population of employees, must be rejected.

\section{Conclusion}

The first of the research hypotheses stated was only partially positively verified; that is, changes in the economic situation influence the employment level in economies in a considerable manner. The second part of the hypothesis was not confirmed because reaction in the Central and Eastern European countries as a whole, was weaker than the European Union's average. The reason for this difference was probably significant deterioration of the situation on the labour market in Greece, Portugal and Spain after 2008, affecting the average obtained for UE-28.

Considering the employment level only, the hypothesis stating that changes in the economic situation decide to a greater extent the employment level among disadvantaged groups (women, youngest and oldest people) than for the general population of employees was not confirmed. Reactions employment in all of these groups reacted to the economic situation were weaker than that of total employment in all the analysed economies. Additionally, level of employment age group 55-64 years reacts inversely to the economic situation. It can be concluded that from macroeconomic point of view, after 2004 year there is no discrimination against women, youth and oldest people in the labor market in the Central and Eastern European countries.

\section{References}

Babos, P. (2014). Step or trap? Transition from fixed-term contracts in Central Eastern Europe. Post-Communist Economies, 26(1). doi:10.1080/14631377.2 014.874230 .

Belan, P., Carré, M., \& Gregoir, S. (2010). Subsidizing low-skilled jobs in a dual labor market. Labour Economics, 17(5). doi:10.1016/j.labeco.2010.04.003.

Burgess, J., \& Connel, J. (2006). Temporary work and human resources management: issues, challenges and responses. Personnel Review, 35(2). doi:10.1108/00483480610645786.

Charlot, O., \& Malherbet, F. (2013). Education and employment protection. Labour Economics, 20. doi:10.1016/j.labeco.2012.09.004.

Charlot, O., Malherbet, F., \& Ulus, M. (2013). Efficiency in a search and matching economy with a competitive informal sector. Economics Letters, 118(1). doi:10.1016/j.econlet.2012.10.017.

Dustmann, C., Glitz, A., \& Vogel, T. (2010). Employment, wages, and the economic cycle: Differences between immigrants and natives. European Economic Review, 54(1). doi:10.1016/j.euroecorev.2009.04.004. 
Eamets, R., \& Jaakson, K. (2014). Labour market flexibility and spatial mobility. International Journal of Manpower, 35(6). doi:10.1108/IJM-05-2014-0123.

Eurostat. (2017). Retrieved 15.02.2017 from http://ec.europa.eu/eurostat.

Fouarge, D., de Grip, A., Smits, W., \& de Vries, R. (2012). Flexible contracts and human capital investments. De Economist, 160(2). doi:10.1007/ s10645-011-9179-0.

Gędek, S., Misiak, T., \& Mentel, G. (2017). Changes in GDP and employment and unemployment in the European Union. Transformations in Business and Economics, 16(3C).

Lenart, Ł., Mazur, B., \& Pipień, M. (2016). Statistical analysis of business cycle fluctuations in Poland before and after the crisis. Equilibrium. Quarterly Journal of Economics and Economic Policy, 11(4). doi:10.12775/EQUIL.2016.035.

Madsen, P.M., \& Bingham, J.B. (2014). A stakeholder: human capital perspective on the link between social performance and executive compensation. Business Ethics Quarterly, 24(1). doi:10.5840/beq2014254.

Reich, M., Gordon, D.M., \& Edwards, R.C. (1973). Dual labor markets: a theory of labor market segmentation. American Economic Review, 63(2).

Rutkowski, J. (2006). Labor market developments during economic transition. Policy Research Working Papers, 3894. doi:10.1596/1813-9450-3894.

Sa, F. (2011). Does employment protection help immigrants? Evidence from European labor markets. Labour Economics, 18(5). doi:10.1016/j. labeco.2011.01.006.

Shortland, S. (2009). Gender diversity in expatriation: evaluating theoretical perspectives. Gender in Management: An International Journal, 24(5). doi:10.1108/17542410910968814.

Walsh, J., \& Deery, S. (1999). Understanding the peripheral workforce: evidence from the service sector. Human Resource Management Journal, 9(2). doi:10.1111/j.1748-8583.1999.tb00196.x.

Williams, C.C. (2009). Rationales for outsourcing domestic services to off-the-books workers. Journal of Economic Studies, 36(4). doi:10.1108/01443580910973565.

Zieliński, M. (2015). Unemployment and labor marker policy in Visegrad Group countries. Equilibrium. Quarterly Journal of Economics and Economic Policy, 10(3). doi:10.12775/EQUIL.2015.032.

\section{Acknowledgements}

Author contributions: author has given an approval to the final version of the article.

Funding: this research was undertaken as part of the Resources and innovations as a source of competitive advantage for the organization project and was fully funded by a grant (NBS 81/17).

Note: the results of this study were presented at 9th International Conference on Applied Economics Contemporary Issues in Economy (June 22-23, Torun, Poland). 


\section{Appendix}

Table 1.

Real GDP growth rate (in \%)

\begin{tabular}{lrrrrrrrrrrrr}
\hline Specification & 2004 & 2005 & 2006 & 2007 & 2008 & 2009 & 2010 & 2011 & 2012 & 2013 & 2014 & 2015 \\
\hline EU-28 & 2.5 & 2.1 & 3.3 & 3.0 & 0.4 & 4.4 & 2.1 & 1.7 & 0.5 & 0.2 & 1.5 & 2.2 \\
Bulgaria & 6.4 & 7.1 & 6.9 & 7.3 & 6.0 & -3.6 & 1.3 & 1.9 & 0.0 & 0.9 & 1.3 & 3.6 \\
Czech Republic & 4.9 & 6.4 & 6.9 & 5.5 & 2.7 & -4.8 & 2.3 & 2.0 & -0.8 & -0.5 & 2.7 & 4.5 \\
Estonia & 6.3 & 9.4 & 10.3 & 7.7 & -5.4 & -14.7 & 2.3 & 7.6 & 4.3 & 1.4 & 2.8 & 1.4 \\
Croatia & 4.1 & 4.2 & 4.8 & 5.2 & 2.1 & -7.4 & -1.7 & -0.3 & -2.2 & -1.1 & -0.5 & 1.6 \\
Latvia & 8.3 & 10.7 & 11.9 & 9.9 & -3.6 & -14.3 & -3.8 & 6.2 & 4.0 & 2.9 & 2.1 & 2.7 \\
Lithuania & 6.6 & 7.7 & 7.4 & 11.1 & 2.6 & -14.8 & 1.6 & 6.0 & 3.8 & 3.5 & 3.5 & 1.8 \\
Hungary & 5.0 & 4.4 & 3.9 & 0.4 & 0.9 & -6.6 & 0.7 & 1.7 & -1.6 & 2.1 & 4.0 & 3.1 \\
Poland & 5.1 & 3.5 & 6.2 & 7.0 & 4.2 & 2.8 & 3.6 & 5.0 & 1.6 & 1.3 & 3.3 & 3.6 \\
Romania & 8.4 & 4.2 & 8.1 & 6.9 & 8.5 & -7.1 & -0.8 & 1.1 & 0.6 & 3.5 & 3.1 & 3.7 \\
Slovakia & 5.3 & 6.8 & 8.5 & 10.8 & 5.6 & -5.4 & 5.0 & 2.8 & 1.7 & 1.5 & -0.7 & 0.2 \\
Slovenia & 4.4 & 4.0 & 5.7 & 6.9 & 3.3 & -7.8 & 1.2 & 0.6 & -2.7 & -1.1 & 3.1 & 2.3 \\
\hline
\end{tabular}

Source: Eurostat (2017).

Table 2.

Coefficients of correlation and determination for GDP changes and changes in total employment and selected groups of employees

\begin{tabular}{|c|c|c|c|c|c|c|c|c|}
\hline \multirow{2}{*}{ Specification } & \multicolumn{2}{|c|}{$\begin{array}{l}\text { GDP change-change } \\
\text { in total employment }\end{array}$} & \multicolumn{2}{|c|}{$\begin{array}{c}\text { GDP change-change } \\
\text { in employment } \\
\text { of women }\end{array}$} & \multicolumn{2}{|c|}{$\begin{array}{l}\text { GDP change-change } \\
\text { in employment } \\
\text { of people aged 15-24 } \\
\text { years old }\end{array}$} & \multicolumn{2}{|c|}{$\begin{array}{l}\text { GDP change-change } \\
\text { in employment } \\
\text { of people aged 55-64 } \\
\text { years old }\end{array}$} \\
\hline & $\begin{array}{l}\text { correla- } \\
\text { tion coef- } \\
\text { ficient }\end{array}$ & $\begin{array}{l}\text { coefficient } \\
\text { of deter- } \\
\text { mination } \\
\text { (in \%) }\end{array}$ & $\begin{array}{l}\text { correla- } \\
\text { tion coef- } \\
\text { ficient }\end{array}$ & $\begin{array}{l}\text { coefficient } \\
\text { of deter- } \\
\text { mination } \\
\text { (in \%) }\end{array}$ & $\begin{array}{l}\text { correla- } \\
\text { tion coef- } \\
\text { ficient }\end{array}$ & $\begin{array}{l}\text { coefficient } \\
\text { of deter- } \\
\text { mination } \\
\text { (in \%) }\end{array}$ & $\begin{array}{l}\text { correla- } \\
\text { tion coef- } \\
\text { ficient }\end{array}$ & $\begin{array}{l}\text { coefficient } \\
\text { of deter- } \\
\text { mination } \\
\text { (in \%) }\end{array}$ \\
\hline EU-28 & $0.7262^{*}$ & 52.74 & $0.6096^{*}$ & 37.16 & 0.2283 & 5.21 & -0.1891 & 3.58 \\
\hline Bulgaria & $0.8032^{*}$ & 64.51 & $0.7839^{*}$ & 61.45 & 0.0842 & 0.71 & -0.5642 & 31.83 \\
\hline Czech Republic & $0.6743^{*}$ & 45.47 & 0.5372 & 28.86 & $0.6851^{*}$ & 46.94 & -0.2429 & 5.90 \\
\hline Estonia & $0.7995^{*}$ & 63.92 & $0.7349^{*}$ & 54.01 & 0.0603 & 0.36 & -0.3641 & 13.26 \\
\hline Croatia & 0.5718 & 32.70 & 0.4321 & 18.67 & 0.3185 & 10.14 & $-0.6683^{*}$ & 44.66 \\
\hline Latvia & $0.8884^{*}$ & 78.93 & $0.8476^{*}$ & 71.84 & 0.3515 & 12.36 & -0.1343 & 1.80 \\
\hline Lithuania & $0.7685^{*}$ & 59.06 & 0.4803 & 23.07 & 0.1386 & 1.92 & -0.0946 & 0.89 \\
\hline Hungary & 0.4793 & 22.97 & 0.3505 & 12.29 & $0.6711^{*}$ & 45.04 & 0.233 & 5.43 \\
\hline Poland & $0.6257^{*}$ & 39.15 & 0.5465 & 29.87 & -0.0983 & 0.97 & -0.5689 & 32.36 \\
\hline Romania & 0.5007 & 25.07 & 0.4594 & 21.10 & 0.3284 & 10.78 & -0.2437 & 5.94 \\
\hline Slovakia & 0.5634 & 31.74 & 0.5207 & 27.11 & $0.6144^{*}$ & 37.75 & $-0.5809^{*}$ & 33.75 \\
\hline Slovenia & $0.7222^{*}$ & 52.16 & 0.5667 & 32.11 & 0.3105 & 9.64 & -0.3466 & 12.01 \\
\hline
\end{tabular}

Note:

* denotes statistical significance level $\mathrm{p}<0.05$.

Source: Own preparation. 
